\title{
Implementation of Adaptive Neuro-Fuzzy Inference System (Anfis) Method on Rice Price Prediction in Lubuklinggau City
}

\author{
Zulfauzi $^{1}$, Budi Santoso ${ }^{2}$, M. Agus Shamsul Arifin ${ }^{3}$, Siti Nuraisyah ${ }^{* 4}$ \\ 1,2,4 Informatics Bina InsanUniversity, Lubuklinggau, Indonesia \\ ${ }^{3}$ Computer System Engineering Bina Insan University, Lubuklinggau,Indonesia
}

\begin{abstract}
Article Info
Article history:

Received 12 01, 2021

Revised 12 25, 2021

Accepted 12 28, 2021

\section{Keywords:}

Prediction,

Adaptive

Neuro-Fuzzy

ANFIS

rice price

ABSTRACT

The problem behind this research is the imbalance between the capacity offered and the capacity demanded by the community, resulting in uncontrolled rice prices, so it is necessary to predict rice price in the future to monitor the stability of rice prices in the Lubuklinggau City area. In this study, the Adaptive Neuro-Fuzzy Inference System (ANFIS) method was used to predict future rice prices. The sample used in this study is data on rice price in Lubuklinggau City from January 2016 to December 2020. The result of the prediction of rice price in the Lubuklinggau City area for the next five years. With the accuracy value in rice price predictions based on MSE training, numely 99,9037\% and based on the MSE test that is 99,8784\%. While the accuracy values of rice price predictions based on MAPE training and testing are $93,2997 \%$ and $88,2782 \%$, respectively. For the accuracy value of rice price prediction result based on the MSE and MAPE values respectively namely $99,8935 \%$ and $92,9212 \%$. It can be concluded that the ANFIS method is very effectively used for the process of predicting a price or value in the future.
\end{abstract}

This is an open access article under the CC BY-SA license.

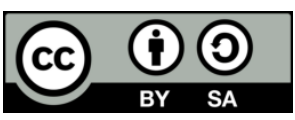

\section{Corresponding Author:}

Siti Nuraisyah

Informatics Bina Insan University

Lubuklinggau, Indonesia

Email: 17010061@mhs.univbinainsan.ac.id

(C) Author 2021

\section{Introduction}

The agricultural sector is a provider of basic foodstuffs for industry as well as sources of foreign exchange in the country. Agricultural development aims to increase agricultural production to meet the food needs of national industries. Until now, the agricultural sector is still the main source of income for most people in Indonesia. Rice is an important commodity for most people in Indonesia in meeting their food needs [1] [2]. The position of rice commodities as raw materials for most of the Indonesian population is a staple food, because almost all Indonesians need rice as the main foodstuff. As well as an important food source in the structure of food, therefore the aspect of supply is very important to maintainthe large number of Indonesian people.

Rice price forecasting is needed to create price stabilization to achieve food security nationally. The increasing number of people in an area is a threat to the resilience of pangan. With a large number 
of people, food supply needs at the national and regional levels continue to grow. To meet the rice needs of the Indonesian population and maintain the stability of rice prices. Therefore, we need a science that studies thepractices that will occur in the future. An activity aimed at predicting what will happen in the future is called forecasting. Food policy, especially rice is a major element in the state budget sector so that one commodity that controls the general price level (inflation). This can allow the government to establish certain food control guidelines. The imbalance between the quantity available and the quantity needed by consumers becomes a factor that can cause price volatility. The supply of rice that producers provide is insufficient throughout the year because it is related to the growing season. Meanwhile, consumer demand will continue throughout the year, because rice is consumed every day, because rice is the main food for the population. .

\section{Research Methodology}

\subsection{Data Collection Methods}

In the method of data collection there are several methods used by authors in finding and processing research objects at the research site, among others:

1. Observation

Observation is an observation of the application studied and intended to produce an overview of the object of research. The author conducted a direct observation of the data collection of rice prices at the Office of theMinistry of Food Of Lubuklinggau City which became a research location to obtain the data and information needed. Such methods are used to collect documents that are a very important source of information that can help in the analysis.

2. Interview

Interview be method Collection data with do tanya answer and methodical with party that Associated of office Resistance Food City Lubuklinggau, so that information that Retrieved from method this Form information about Ofhe price rice and Problems that become reason climb or Decline price rice.

3. Documentation

In this method, the researcher makes observations by documenting objects related to the data needed by the researcher.

4. Library Studies

In this method data collection is done by studying books related to rice price prediction and the use of selected methods. In addition, it can talk references from the internet and e-books, guidebooks, journals, referencesi from textbooks for the need to analyze and use methods that will be proposed.

\subsection{Population, Sampling Techniques, and Research Samples}

The population used in this study is all rice price data in the Food Security Office of Lubuklinggau City. Sampling technique in sampling is Purposive Sampling which considers samples that have the necessary information bagi researchers. The sample that the researchers considered was rice price data at the Lubuklinggau City Food Security Office from January 2016 to December 2020.

For rice price data itself is the result of a survey obtained by every sub-district in the city of Lubuklinggau. Where the price data from each sub-district is recorded by staff in each sub-district who conducted a survey to the stalls, then the data is given to the City Food Security Office Lubuklinggau, the thing that also causes the existing rice price data is relatively slightly higher than the price in the market, because the Food Security Office of Lubuklinggau City is only Monitor the price of rice at the consumer level only.

The implementation of the Adaptive Neuro-Fuzzy Inference System (ANFIS) method on rice price prediction in the city of Lubuklinggau, is a quantitative study. [3] Meanwhile, for data collection methods in the form ofliterature studies, documentation, interviews and observations with the aim of facilitate researchers in collecting data and references. related to research and for data development methods in this study using pseudocode and flowchart, with the aim to see the stages of each method of processing the method used.

Research on the implementation of the Adaptive Neuro-Fuzzy Inference System (ANFIS) method on rice price prediction in the city of Lubuklinggau, consists of several stages, namely: 


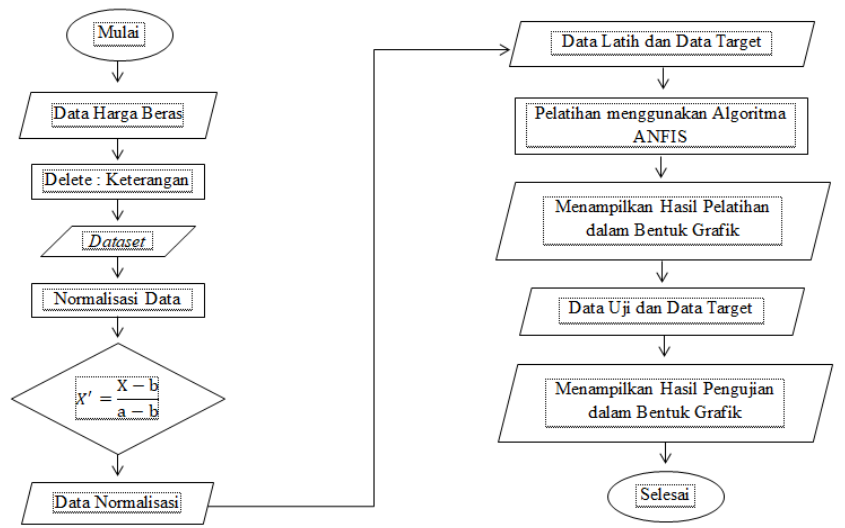

Figure 1. Flowchart Prediction System

The flow of the rice price prediction system using the ANFIS method can be seen in the picture above, with a description of each step, namely:

1. Enter original price data

2. Delete unnecessary columns

3. Showing Dataset

4. Perform data normalization, with formula $\mathrm{X}^{\prime}=\mathrm{x}-\mathrm{b} / \mathrm{a}-\mathrm{b}$

5. Display normalization data results

6. Perform training data process and target data

7. Conduct training with ANFIS algorithm

8. Show training results in diagram format

9. Perform ice prosdata test and targettest

10. Display test results in graphic form

\section{Results and Discussions}

\subsection{Research Results}

3.1.1 Preprocessing

In this prenelitian characteristics or features that will be used to predict the price of rice is the price of rice per week in the city of Lubuklinggau for 5 (five) years, from January 2016 to January 2016. with December 2020 predicted to use matlab application. Before the data mining process can be done, a preprocessing stage is needed. At this stage will be carried outa process of combining some data, then cleaning is done to get the appropriate dataset so that it can be used at the next stage. At that stage did not combine the data because the data taken came directly from the data design obtained from the Food Security Office of Lubuklinggau City.

Here is a sample from the Preprocessing of rice prices at the Department of Food Security of Lubuklinggau City:

\begin{tabular}{|c|c|c|c|c|c|}
\hline Year & & WEEK 1 & WEEK 2 & WEEK 3 & WEEK 4 \\
\hline \multirow{9}{*}{2016} & JANUARY & 9550 & 9875 & 9813 & 9938 \\
\hline & FEBRUARY & 10000 & 9938 & 9938 & 10000 \\
\hline & MARCH & 10500 & 10344 & 10563 & 10563 \\
\hline & APRIL & 10188 & 10188 & 9563 & 9563 \\
\hline & MAY & 9250 & 9313 & 9250 & 8938 \\
\hline & JUNE & 9188 & 9250 & 9375 & 9063 \\
\hline & JULY & 9250 & 9250 & 9313 & 9063 \\
\hline & AUGUST & 9500 & 9500 & 9625 & 9500 \\
\hline & SEPTEMBER & 9375 & 9438 & 8875 & 9438 \\
\hline
\end{tabular}




\begin{tabular}{|c|c|c|c|c|c|}
\hline & OCTOBER & 8875 & 8875 & 8875 & 8875 \\
\hline & NOVEMBER & 8875 & 9125 & 9375 & 9375 \\
\hline \multirow{13}{*}{2017} & DECEMBER & 9375 & 9714 & 9500 & 9375 \\
\hline & JANUARY & 9571 & 9714 & 9429 & 9875 \\
\hline & FEBRUARY & 9813 & 9875 & 10063 & 9875 \\
\hline & MARCH & 10063 & 9938 & 9938 & 9750 \\
\hline & APRIL & 9688 & 9613 & 9375 & 9438 \\
\hline & MAY & 9563 & 9688 & 9688 & 9688 \\
\hline & JUNE & 9813 & 9563 & 9438 & 9646 \\
\hline & JULY & 9313 & 9438 & 9313 & 9375 \\
\hline & AUGUST & 9500 & 9563 & 9500 & 9688 \\
\hline & SEPTEMBER & 10500 & 9688 & 9813 & 9875 \\
\hline & OCTOBER & 9500 & 9750 & 9875 & 9938 \\
\hline & NOVEMBER & 9500 & 10250 & 10563 & 10563 \\
\hline & DECEMBER & 10750 & 11063 & 10188 & 10563 \\
\hline \multirow{12}{*}{2018} & JANUARY & 11214 & 12750 & 11214 & 12071 \\
\hline & FEBRUARY & 11214 & 11214 & 12071 & 12071 \\
\hline & MARCH & 10714 & 10717 & 10875 & 10875 \\
\hline & APRIL & 10875 & 10438 & 10875 & 10438 \\
\hline & MAY & 10250 & 10256 & 10375 & 10063 \\
\hline & JUNE & 10250 & 10063 & 10000 & 10438 \\
\hline & JULY & 10188 & 10188 & 10438 & 10750 \\
\hline & AUGUST & 10250 & 10250 & 10500 & 10188 \\
\hline & SEPTEMBER & 10188 & 10188 & 10375 & 10375 \\
\hline & OCTOBER & 10125 & 10125 & 10125 & 10125 \\
\hline & NOVEMBER & 10375 & 10250 & 10250 & 10375 \\
\hline & DECEMBER & 10375 & 10375 & 10406 & 10438 \\
\hline \multirow{12}{*}{2019} & JANUARY & 10500 & 10313 & 10688 & 10438 \\
\hline & FEBRUARY & 10438 & 10625 & 10250 & 10188 \\
\hline & MARCH & 10250 & 10313 & 10313 & 10438 \\
\hline & APRIL & 11125 & 10813 & 11313 & 10813 \\
\hline & MAY & 10438 & 10313 & 9750 & 9625 \\
\hline & JUNE & 10125 & 9875 & 9750 & 9625 \\
\hline & JULY & 10125 & 9875 & 9750 & 9563 \\
\hline & AUGUST & 9750 & 10000 & 9938 & 9525 \\
\hline & SEPTEMBER & 9250 & 9338 & 9150 & 9188 \\
\hline & OCTOBER & 9250 & 9250 & 9188 & 9125 \\
\hline & NOVEMBER & 9275 & 9188 & 9250 & 9188 \\
\hline & DECEMBER & 9313 & 9250 & 9125 & 9125 \\
\hline \multirow{4}{*}{2020} & JANUARY & 9275 & 9188 & 9250 & 9188 \\
\hline & FEBRUARY & 9313 & 9250 & 9125 & 9125 \\
\hline & MARCH & 10063 & 9813 & 9813 & 10313 \\
\hline & APRIL & 10063 & 10000 & 9875 & 10000 \\
\hline
\end{tabular}




\begin{tabular}{lrrrr}
\hline MAY & 10188 & 10063 & 10250 & 10250 \\
\hline JUNE & 10000 & 10000 & 9875 & 9938 \\
\hline JULY & 9875 & 10000 & 10313 & 10313 \\
\hline AUGUST & 10688 & 10625 & 10625 & 10625 \\
\hline SEPTEMBER & 10313 & 10250 & 10250 & 10563 \\
\hline OCTOBER & 10500 & 10375 & 10250 & 10438 \\
\hline NOVEMBER & 10500 & 10375 & 10313 & 10313 \\
\hline DECEMBER & 10313 & 10313 & 10625 & 10500 \\
\hline
\end{tabular}

From the rice price data above can be seen the difference in price in each month, where the difference is caused by various factors, namely weatherfactors, pest disturbances, harvest, reduce rice fields, the presence of imported rice and rice exports and grain price factors.

\subsubsection{Data Normalization}

In this section is done data normalization [4], where the data used is the original data which is then applied using the formula of normalization of ANFIS data, using the following formula.

Where:

$$
\mathrm{X}^{\prime}=(\mathrm{X}-\mathrm{b}) /(\mathrm{y}-\mathrm{z})
$$

$\mathrm{X}^{\prime}=$ Data normalization results

$\mathrm{X}=$ preliminary data

$\mathrm{y}=$ the largest number of data

$\mathrm{z}=$ the smallest number of data

\subsection{Application of Methods and Testing}

The steps to implement the Adaptive Neuro-Fuzzy Inference System (ANFIS) method are:

1. Determination of Training Data and Training Targets (Training)

In this process, the price of rice is predicted to be sourced on rice price data 2 weeks before that. For data trains starting from the data of the 1st week of January 2016 to the 142nd week of December 2018, while for the training target starting from the data of the 3rd week of January 2016 until the 144th week of December 2018. Where to determine the training data using the formula zeros (numberof months $\times$ years of training - training week, training week). As for determining the training target using the formula zeros (numberof months $\times$ years of training - training week, 1). Then to determine the results of the prediction of the target train is to use the formula (output training $\times$ (maximal_data-minimum data)) + minimum data. This zeros disfunctionis to determine the data value of the range $0-1$.

Table 2 Training Data Arrangements and Training Targets

\begin{tabular}{clll}
\hline Half & \multicolumn{2}{c}{ Training Data } & Training Targets \\
\hline 1 & Data in weeks & $1-2$ & Week 3 data \\
\hline 2 & Data in weeks & $2-3$ & Week 4 data \\
\hline 3 & Data in weeks & $3-4$ & Week 5 data \\
\hline 4 & Data in weeks & $4-5$ & 6th week data \\
\hline 5 & Data in weeks & $5-6$ & Week 7 data \\
\hline$\cdot$ & &. & $\cdot$ \\
\hline$\cdot$ & &. & $\cdot$ \\
\hline$\cdot$ & &. & $\cdot$ \\
\hline$\cdot$ & &. & 141st week data \\
\hline 139 & Data in weeks & $139-140$ & 142nd week data \\
\hline 140 & Data in weeks & $140-141$ & 143rd week data \\
\hline 141 & Data in weeks & $141-142$ & 144th week data \\
\hline 142 & Data in weeks & $142-143$ &
\end{tabular}


2. Training using ANFIS Algorithms

In thisprocess, training is carried out with ANFIS algorithm with input in the form of data trains and target trains that have previously been obtained, then conduct ANFIS training with data training. using training data and training targets.

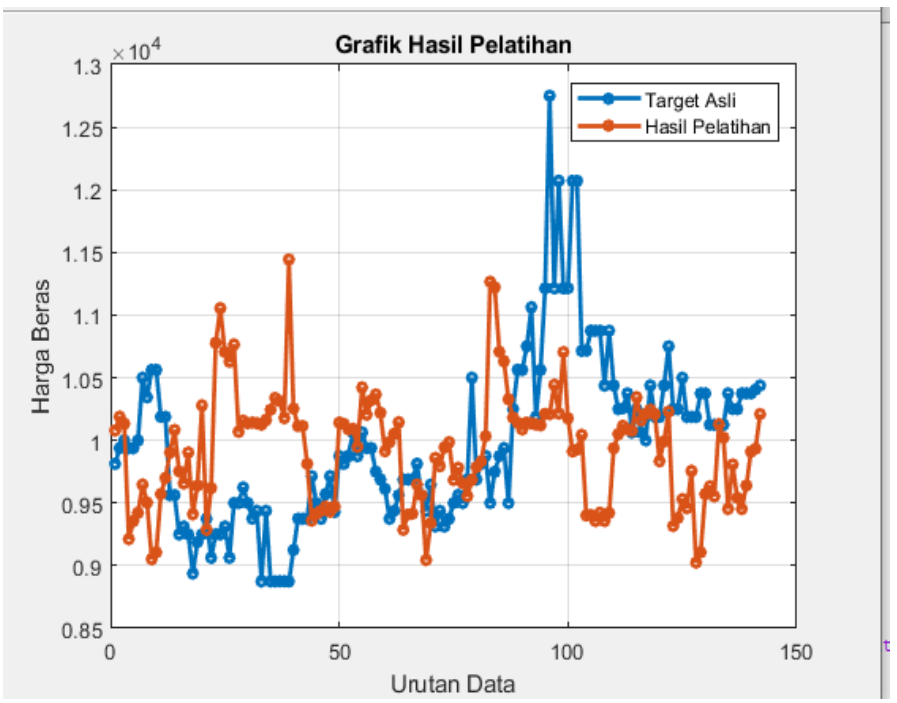

Figure 1 Training Results Graph

3. Determination of Test Data and Test Targets (Testing)

At this stage, the price of rice is predicted to be sourced on rice price data 2 weeks before that. For test data starting from the data of the 143rd week of January 2019 with the 238th week of December 2020, while for the test target starting from the data of the 145th week of January 2019 until the with the 240th week of December 2020.

Table 3 Test Data Arrangement and Test Targets

\begin{tabular}{|c|c|c|}
\hline Half & Test Data & Test Target \\
\hline 1 & Data in weeks $143-144$ & 145th week data \\
\hline 2 & Data in weeks $144-145$ & 146th week data \\
\hline 3 & Data in weeks $145-146$ & Week 147 data \\
\hline 4 & Data in weeks $146-147$ & Week 148 data \\
\hline 5 & Data in weeks $147-148$ & Week 149 data \\
\hline 6 & Data in weeks $148-149$ & 150th week data \\
\hline 7 & Data in weeks $149-150$ & 151st week data \\
\hline 8 & Data in weeks $150-151$ & 152nd week data \\
\hline 9 & Data in weeks $151-152$ & 153rd week data \\
\hline - & • & • \\
\hline$\cdot$ & $\cdot$ & $\cdot$ \\
\hline$\cdot$ & $\cdot$ & $\cdot$ \\
\hline$\cdot$ & $\cdot$ & $\cdot$ \\
\hline • & • & • \\
\hline 92 & Data in weeks $234-235$ & 236th week data \\
\hline 93 & Data in weeks $235-236$ & 237th week data \\
\hline 94 & Data in weeks $236-237$ & 238th week data \\
\hline 95 & Data in weeks $237-238$ & 239th week data \\
\hline
\end{tabular}




\begin{tabular}{|l|l|l|}
\hline 96 & Data in weeks 238-239 & 240th week data \\
\hline
\end{tabular}

Where to determine the test data using the formula zeros (numberof months $\times$ the test year, test week). As for determining the test target using the formula zeros (numberof months $\times$ the test year, 1). Then to determine the results of the test target prediction is to use the formula (output testing $\times$ (maximal data - minimum data)) + minimum data.

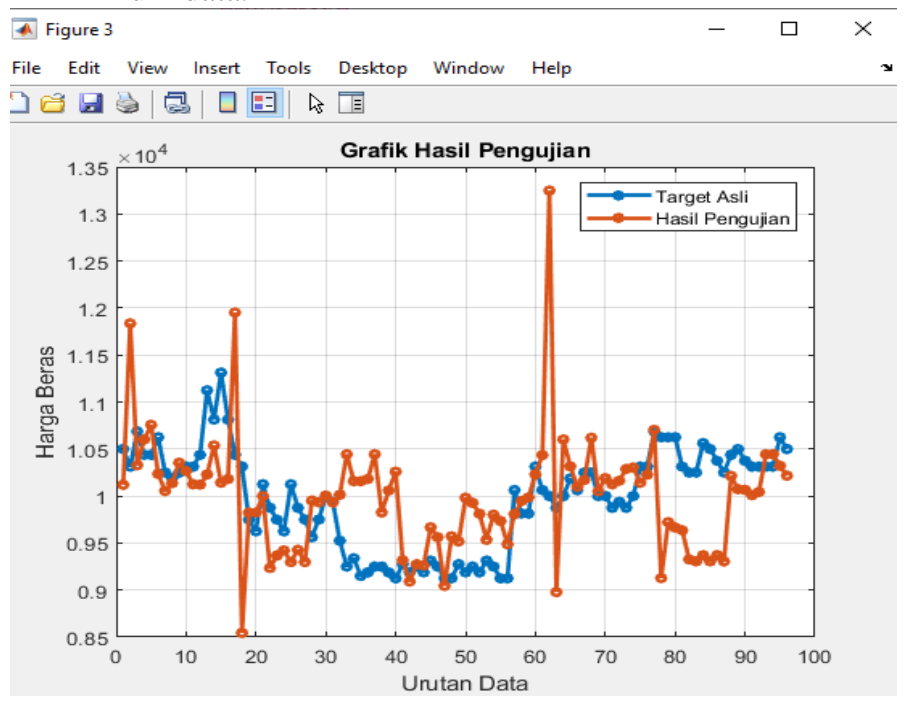

Figure 2 Test Results Graph

4. Determining prediction results

In this stage, the price of rice that will be predicted is sourced from rice price data 5 years earlier. The prediction data used is the price of rice from January 2016 to December 2020 (5 years). Then there will be an application on the matlab application. Where to determine prediction data using the formula zeros (numberof months $\times$ year prediction, prediction week). As for determining the prediction target using the formula zeros (numberof months $\times$ year prediction - prediction week, 1). Kemudian to determine the results of predictions is using formulas (out prediction $\times($ max data - min data) $)+\min$ data.

Table 4 Prediction Results

\begin{tabular}{|c|c|c|c|c|c|}
\hline \\
\hline No. & $\begin{array}{c}\text { Original } \\
\text { Data } \\
\text { Prediction } \\
\text { Target }\end{array}$ & $\begin{array}{l}\text { Prediction } \\
\text { Results }\end{array}$ & Information & Moon & Year \\
\hline 1 & 9813 & 10020 & Prices Go Up & \multirow{4}{*}{ January } & \multirow{8}{*}{2021} \\
\hline 2 & 9938 & 10260 & Prices Go Up & & \\
\hline 3 & 10000 & 10260 & Prices Go Up & & \\
\hline 4 & 9938 & 9328 & $\begin{array}{l}\text { Prices } \\
\text { Down }\end{array}$ & & \\
\hline . & . & . & . & \multirow{4}{*}{ • } & \\
\hline . & . & . & . & & \\
\hline . & . & . & . & & \\
\hline - & - & . & - & & \\
\hline 233 & 10313 & 10010 & $\begin{array}{l}\text { Prices Are } \\
\text { Down }\end{array}$ & \multirow{4}{*}{ November } & \multirow{6}{*}{2025} \\
\hline 234 & 10313 & 10310 & $\begin{array}{l}\text { Prices Are } \\
\text { Down }\end{array}$ & & \\
\hline 235 & 10313 & 10340 & Prices Go Up & & \\
\hline 236 & 10313 & 10380 & Prices Go Up & & \\
\hline 237 & 10625 & 10370 & $\begin{array}{l}\text { Prices Are } \\
\text { Down }\end{array}$ & \multirow{2}{*}{ December } & \\
\hline 238 & 10500 & 10410 & $\begin{array}{l}\text { Prices Are } \\
\text { Down }\end{array}$ & & \\
\hline
\end{tabular}

From the prediction results obtained the mse value prediction $0.1065 \%$ and the prediction MAPE value $7.0788 \%$, with accuracy values based on MSE and MAPE values of $99.8935 \%$ and $92.9212 \%$, of 
$99.8912 \%$ and $92.9212 \%$, among them. Based on the results of the above predictions it can be concluded that the use of metode Adaptive Neuro-Fuzzy Inference System (ANFIS) on rice price prediction is very good and suitable for predicting rice prices. .

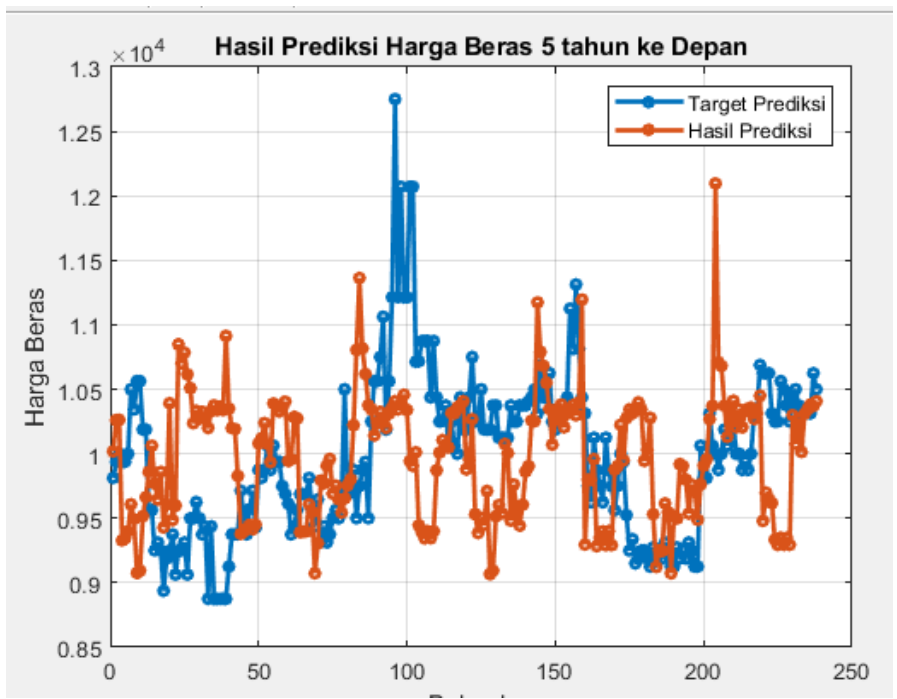

\section{Data Validation}

Figure 3 Graph of Rice Price Prediction Results

The need for data validation to ensure accuracy will level the level of variable-veriabel data in research that unites the period of research methods with research objects using existing data. The data used to validate the data is training data and testing data.

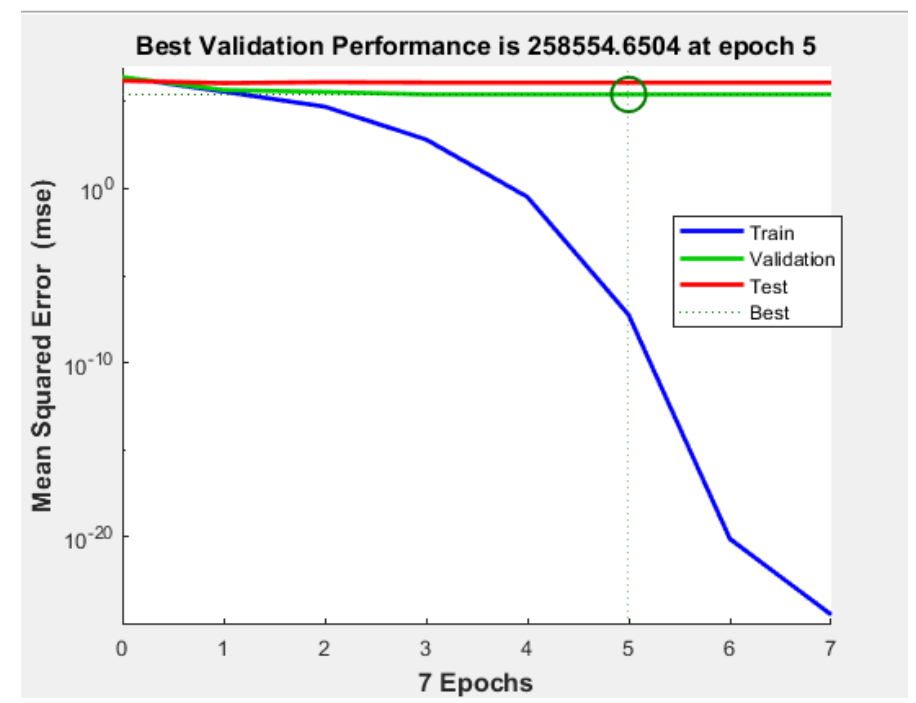

Figure 4 Best Validation Performance Graph

For each data validation check, the results obtained can vary due to the data used as random data or random data.

Validation performance values that have been done using training data and test data as the target, with Random 96 target timesteps data divided into 68 target timesteps data, 14 timesteps targets as validation and 14 targets timesteps as data tests. So get the best value is 258554.6504 in epoch 5 . 

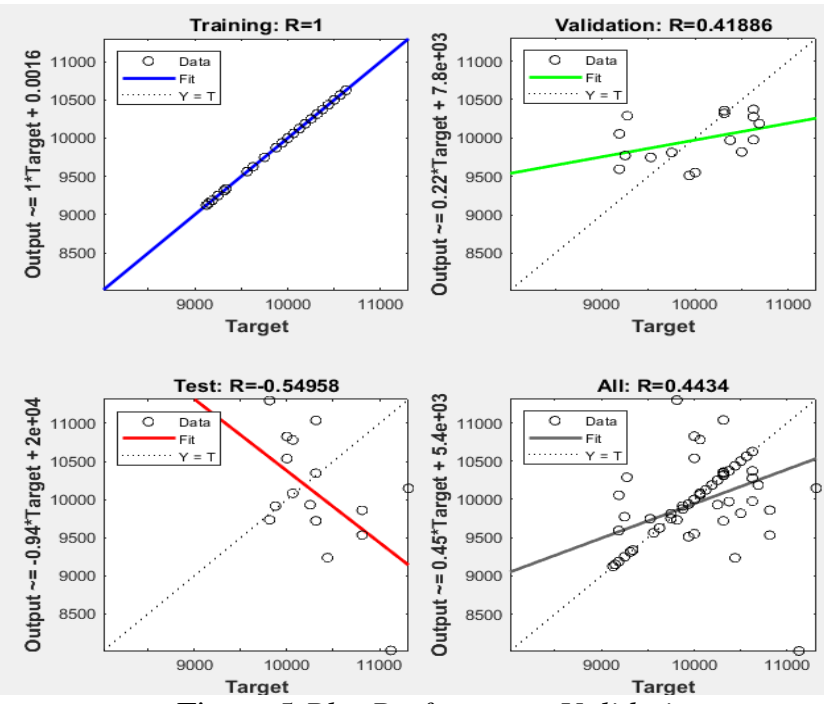

Figure 5 Plot Performance Validation

In the performance validation results show regression values that aim to measure the correlation value between output and target, where in training $\mathrm{R}=1$, in validation $\mathrm{R}=0.41886$, test $\mathrm{R}=0.54958$, and in all performances $\mathrm{R}=0.4434$. If, the value of $\mathrm{R}$ is 1 indicates that performance has the closest relationship, while 0 is a random relationship. In the validation results above shows that the method listed is Regression because in the matlab application there is a default tool to perform a valid process of breast milk, namely network time series tools (ntstool) so that the validation results are regression. Adaptive Neuro-Fuzzy Inference System (ANFIS) is part of regression. For each time to validate data, the results obtainedn can vary because the data done for the validation process is random data taken from existing training and test data.

\section{Conclusion}

Based on the results and discussions that have been done, the conclusions obtained in this study are: Researchers can find out how to make predictions and how much accuracy predictions are obtained using the Adaptive Neuro-Fuzzy Inference System (ANFIS) method. MAPE(Mean Absolute Percentage Error) and MSE (MeanSquareError) values from rice price prediction results in Lubuklinggau City using the ANFIS method, where for mape value training of $6.7003 \%$ and MSE value by $0.0963 \%$ while for testing mape values by $11.7218 \%$ and nilai MSE by $0.1216 \%$.

For the accuracy value on rice price prediction based on MSE training which is $99.9037 \%$ and based on MSE testing which is $99.8784 \%$. While the accuracy value of rice price predictions based on MAPE training and testing is $93.2997 \%$ and $88.2782 \%$ For prediction MSE values of $0.1065 \%$ and MAPE values of predictions $7.0788 \%$, with accuracy values based on MSE and MAPE values of $99.8935 \%$ and $92.9212 \%$, of 99.8212 , are $99.8935 \%$ and 92.9212 , years, of year.

The ANFIS method is an effective method for making price predictions in the future.

\section{References}

[1] A. Fauzi and T. Hidayatulloh, "Penilaian Kinerja Karyawan Pada PT. Telecom Visitama Menggunakan Metode Analytical Hierarchy Process," Indones. J. Comput. Inf. Technol., vol. 2, no. 2, pp. 65-71, 2017.

[2] Directorate General of BP Holtikultura,"Rice commodity profile," Ews.Kemendag. Go.Id,2003, [Online]:https://ews.kemendag.go.id/sp2kplanding/assets/pdf/130827_ANL_UPK_Beras.pdf.

[3] C. O. Doaly, P. Moengin, and G. Chandiawan, "Pemilihan Multi-Kriteria Pemasok Department Store Menggunakan Metode Fuzzy Ahp Dan Topsis,” J. Ilm. Tek. Ind., vol. 7, no. 1, pp. 70-78, 2019, doi: 10.24912/jitiuntar.v7i1.5037.

[4] M. H. Siregar, "Data Mining Klasterisasi Penjualan Alat-Alat Bangunan Menggunakan Metode KMeans (Studi Kasus Di Toko Adi Bangunan),” J. Teknol. Dan Open Source, vol. 1, no. 2, pp. 83-91, 2018, doi: 10.36378/jtos.v1i2.24. 
[4] A. Cashmere,"Understanding and Types of Predictions, Forecasting and Implementation," Preda Media, 2003. https://initu.id/amp/understanding-and-type-prediction-forecasting-forecasting-andimplementation/.

[5] A. Finally,"Digital Image Processing, Video Processing, Pattern Recognition, and Data Mining," 2018. https://pemrogramanmatlab.com/2018/12/31/prediksi-harga-saham-menggunakan-algoritmaanfis/\#more-7256.

[6] M. Darussalam,"Implementation of Adaptive Neuro Fuzzy Inference System for Student Duty Admission Selection System at Smk Prima Wisata Jakarta," None, vol. 13, no. 1, pp. 66-75, 2017.

[7] F.M. Siregar,G. W. Nurcahyo, and S. Defit,"Predictionof The Results of The Competency Examination of Doctor Profession Program (UKMPPD) students with ANFIS Approach," J. RESTI (Sist. and Teknol Engineering. Information), vol. 2, no. 2, pp. 554-559, 2018, doi: 10.29207/resti.v2i2.388.

[8] W. Rahayu,"Model of Determining Outstanding Teachers Based on Adaptive Neuro Fuzzy Inference System(Anfis),"J. Sisfotek Glob., vol. 7, no. 1, pp. 101-107, 2017, [Online]. Available: https://journal.stmikglobal.ac.id/index.php/sisfotek/article/view/134. 